\title{
BRASILIAN RELIEF: STRUCTURES AND FORMS
}

\author{
Jurandyr Luciano Sanches Ross ${ }^{1}$
}

\begin{abstract}
The forms of Brazilian relief cannot be understood without the comprehension of what occurs with the South America relief. The structural and sculptural processes developed in Brazilian relief are straightly related with the Atlantic opening and the formation of Andes Orogenic Chains. The Meso-Cenozoic epeirogenesis unleashed the denudational processes that set a definite mark in Brazilian relief formation. The great forms are associated with structures of Cratons, Orogenic Belts and Sedimentary Basins. These great morphologies are produced by several Pre and Post-Cretaceous erosive phases under the effect of the ancient tectonic and the Cenozoic. High altimetry positions coincide with lithologies of igneous mass and rocks of high metamorphism and, downgraded reliefs sculpted on rocks of low metamorphism that suggest important effects of chemical detritions operating on the genesis of shapes of the Brazilian relief.
\end{abstract}

KEY WORDS: relief, structural processes, sculptural processes, macro morphologies.

\section{INTRODUCTION}

For a better understanding of the Brazilian relief, it is important to contextualize it in a South American large subdivision and geodynamics.

In a simple way, the relief of South America can be described as having on its western coast the Andes, which formation started in the Mesozoic and lasted until the Cenozoic. It follows the Andes Cordillera from the north to the south (from Venezuela to Argentina) in the Midwestern part of the continent, an area consisting of lowlands of plains and depressions mostly sculpted on recent Cenozoic sediments. In the middle-eastern part of the continent are the structures and the old lithological formations that refer to the Pre-Cambrian and are, in partially covered by long sedimentary Phanerozoic basins. In this area a great extension of plateaus and mountain ranges prevail connected with corridors of the so-called Periphery and Interplateau Depressions.

While the Andes Cordillera, which is relatively narrow extended from north to south is very high, its altitude exceeds 4000 meters in many areas; the lands in the central and on the eastern parts are lower, being the altitude below 1000 meters. In this area, land is affected by several erosive degradation phases, originating great sedimentary basins.

\footnotetext{
${ }^{1}$ Geógrafo formado pela Universidade de São Paulo. Mestrado e doutorado em Geografia (Geografia Física) pela Universidade de São Paulo. Professor titular da Universidade de São Paulo. E-mail: juraross@usp.br 
Brazilian territory is formed by ancient geological structures. However, there are some recent sedimentary basins such as Pantanal in Mato Grosso state, the western Amazon Basin ( Solimões Basin), the east coast, northest and south and small Cenozoic basins formed in the tectonic depressions in laid in crystaline great structures on the east, north and south coast.

In Brazil, although the structures and lithological formations are mostly old, the shapes of the relief are recent. These were caused by the Meso-Cenozoic tectonic effects and erosive degradation that are continuously reshaping them. Consequently, shapes of the Brazilian relief have as a genetic mechanism, on one side the lithological formations and old structural dispositions and, on the other side, the most recent processes associated with the motion of tectonic plates and the erosive degradation of present and ancient climate. Great part of rocks and structures that sustain the shapes of Brazilian relief precede the present South American configuration, which began to have its shape with the Andes orogeny associated with the opening of the Atlantic, in the Meso-Cenozoic Period.

In a simple way, there are three great structures that define the great compartments of the Brazilian relief: the platforms or Cratons, the Orogenic Belts and the sedimentary basins.

The platforms or Cratons correspond to the older and devastated lands caused by many phases of erosion. A large lithological complexion, prevailing very old metamorphic rocks (Middle Pre-Cambrian to Lower, over 2,5 billion years). There are also metamorphic and old intrusive rocks (Middle Pre-Cambrian to Superior, aged between 800/900 million and 2 billion years) and the waste of sedimentary rocks dating the Pre-Cambrian Superior, that partially cover these Cratons or platforms. These areas are represented by Amazônica, São Francisco and Uruguaio-Sulriograndense platforms.

The orogenic belts, which correspond to a long extension of folded structures in Brazil, are very old corresponding to various phases along the Pre-Cambrian Period. These belts are: the Atlantic, Brasilia and Paraguai-Araguaia. These three old mountain chains are now deteriorated by several erosive phases, although long extensions of land still maintain the mountainous aspect. These lands were in the past sedimentary basins that were folded several times by crust pressure. The sediments, as being folded, also suffered metamorphism, intrusion and volcanic effusion. Some of these orogenic areas, as the Atlantic Belt, have experienced up to three folding phases, along with metamorphism and intrusions alternating with long erosive phases. 
The third kind of structure that appears in Brazilian territory is the so-called sedimentary basins: the Amazônica, Paraíba or Maranhão, Paraná and Parecis. These basins were formed in the Phanerozoic Period, in other words, in the last 550 million years. The sediments are from the Paleozoic, Mesozoic and Cenozoic Periods. When the basins were created, the South American lands were in much lower altimetry positions. The glacial sea and continental deposits formed the sedimentary rocks in these three great basins. Thus, different kinds and ages of sandstone are found there, sometimes added to siltstones, argillites, conglomerates and limestones. Specifically, in Paraná Basin, in the Jurassic Period, there was an extensive spread of volcanic lava predominantly basaltic, accommodated in sedimentary layers stratified and horizontally plane.

The Cenozoic deposits from the Tertiary Period are most extensively found in the western area of the Amazon Basin and on the coast. Tertiary-Quaternary sedimentary basins were also formed in the rift-valleys, generated concomitantly with respective tectonic depressions from middle Vale do Paraiba, the south of Rio de Janeiro and São Paulo State, Alto do Tietê in the city of São Paulo, lower Vale do Ribeira in São Paulo state among others in the national territory. The Cenozoic sediments, the Quaternary Period are most extensively found in Pantanal (Mato Grosso State), on the coast of Rio Grande do Sul state, Bananal Island in the Araguaia River and the plains along the Amazon River and lower courses of its tributaries.

In the Mesozoic (Cretaceous Period) occurred the last extensive deposit phase in sedimentary basins in Brazil, except for Amazon, which received sediments along the Tertiary. In the Meso-Cenozoic, the South American continent suffered orogeny on its western border (Andes Cordillera) and epirogenesis in the other areas. These warpings reached Brazilian territory, unequally because some areas were being more lifted than others.

This process, together with tectonic plates, uplifted the Cratons, the Orogenic Belts as well as the sedimentary basins. It was in the epirogenesis, predominantly Cenozoic, which the sedimentary basins were located in higher altimetry levels. This tectonic process unleashed a general and long erosive degradation that acted most effectively in the sedimentary basins, originating on its borders the so-called Depressions Periphery and Interplateau. Erosive processes, which concomitantly occurred with the epirogenesis phase, in the Tertiary and 
Quaternary, had different characteristics. For over 70 million years, erosive degradation occurred in climatic environments oscillating from hot and wet, and arid or semi arid.

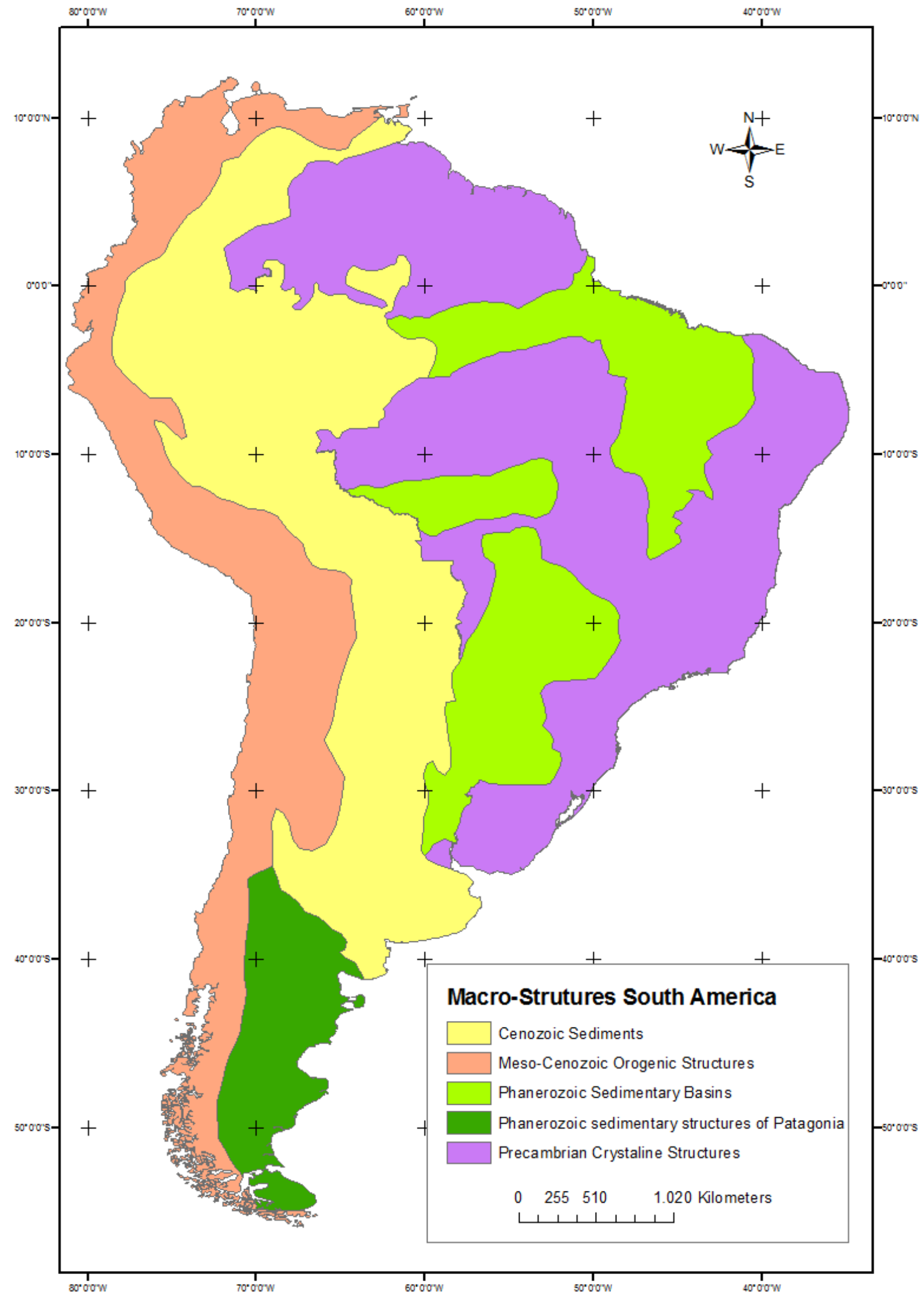

Figure 1: The great structures of South American (Almeida, 2004). 


\section{Sculptural Processes: the erosion surface}

About tectonic processes and erosion, several researchers gave significant contributions, which include: Moraes Rego (1933), De Martonne (1943), Ruellan (1944), Freitas (1951), Ab'Saber (1949,1957,1958, 1960, 1964, 1969, 1984, and 2001), Almeida (1949, 1958,1964,1976, 1988), King (1956), Bigarella (1965), Silveira (1953), Ross (1987, 1990, 1991,1997, 2002) among others.

De Martonne's work (1943), called "Problemas morfologicos do Brasil tropical úmido", despite of having considered the effects of tectonics that affected the East-Southeast of Brazil, gave great importance to morphological levels that identified various stages of erosion which was called: Superficies Pre-Permiana, do Campos, das Cristas Médias and Neogenica.

The Pre-Permian surface, considered by De Martonne (1943), as erosion surface fossil corresponds to a slope of Carboniferous and Permian sediments of Paraná Basin, at the height of 550-600 meters, and protrudes upward, touching the tops of appalachian crest of crystalline terrains, reaching approximately 1.600 meters.

The area of Campos was basically established on the rectilinear tops of Serra da Mantiqueira, that were around 1400-1500 meters, referring to a natural vegetation of fields of Campos do Jordao, and Ribeirão Fundo, possibly linked to the Cretaceous.

The Superficie de Cristas Médias, which tops of hills and ridges provide a flat imaginary surface, is located between 1000-1100 meters. It was dated by De Martonne as Paleogenetic, means to the Lower Tertiary. This level of erosion are present on the tops of Jaraguá Peak, Japi ridge, Cantareira ridge , among others, which higher parts are above the altimetry mentioned. The surface area of crystalline terrains of eastern São Paulo, coincides with boulders associated with granitic intrusions (Serras: of Cantareira, Itapeti, San Roque, San Francisco, Itaqui and the southern part of Japi), or structural blocks of hard metamorphic quartzite (Jaragua Peak and part of Japi Ridge) that offer greater resistance to weathering processes and consequently wearing, from both chemical and physical action.

The Neogene surface, De Martonne (19430, is considered the terrain that arise up between 800-900 meters, that include parts of Vale do Paraiba, Alto Tietê, protruding slightly to west, corresponding to the level of the tops of the hills of Depressão Periférica. This surface dated, therefore, between the Upper Tertiary and Quaternary Bottom (Pliocene- 
Pleistocene), coincide with what was called Superficie de São Paulo by Almeida (1964), which involves both the crystalline terrains as the sedimentary ones of São Paulo Basin, which higher sectors (800-830 meters) leveled with crystalline slightly flattened terrains around São Paulo city.

The Lester King (1956) contributed with the work "Geomorfologia do Brasil Oriental" after an exhaustive field analysis associated to cartographic documentation and geological products. He formulated an interpretation of Brazilian relief evolution, associating it to African Continent. The contribution of King (1956) has merit, especially because the put the country to another path interpretation: the erosion of polycycle, as well he used the concept of pediments pediplanation for interpreting Brazilian relief genesis, as well to analyze the generalized uplift phases effect on Continental block, alternated with stages of erosion by scarp regressions and pedimentation.

The key to interpreting Brazilian relief developed by King (1956) part from his statement: "The fundamental element of Brazilian scenario is the vast plain produced by denudation between the Lower Cretaceous and Medium Tertiary, after been uplifted, it became dissected by polycyclic erosion ". This vast plain was called "Superficie Sul Americana" or "Peneplanação Sul Americana", turning itself, according to King(1956), the key for understanding Cenozoic morphogenetic evolution of Brazil.

The records of previous cycles as Gondwana (Early Cretaceous to Jurassic) and the PostGondwana (Upper Cretaceous) were found by fossilized deposits of Cretaceous, the old cycles (Upper Tertiary) and Paraguaçu (Pleistocene) dissect the South American Surface and thus their records were inserted in the latter, which was wider.

The contribution of Bigarella, Mousinho and Silva (1965) about the erosion surfaces came from studies to create a model for interpreting the evolution of Brazilian relief. From studies realized, by these authors in South and Southeast of Brazil, especially on Serra do Mar region, it was published a work called "Pediplano, Pedimentos e seus Depósitos Correlativos no Brasil". It proposed three major phases occurred by erosive pediplanation.

That interpretation had influence from Lester King (1956) and Walter Penck and conceived that the slopes develop themselves by parallel decline in arid and semi-arid areas. And in this process they generate flattened and destroyed by erosion surfaces. Such surfaces are defined through the Pediments and coalescence of these defines pediplains. The activity occured on one side implies the deposition of sediments on the other one, the called 
correlative deposits. Thus, it is implied that each erosive phase, there should be a sedimentation correspondence. These authors identified three areas of the pediplanation that they called: $\mathrm{Pd} 1, \mathrm{Pd} 2$ and $\mathrm{Pd} 3$, that must correspond to three significant correlative deposits, called: P1, P2 and P3. In order to establish the relationship between age and genesis, the authors suggest to Pd3, Cretaceous-Eocene age, coinciding with the Cretaceous sedimentation throughout Brazil.

This surface called Pd3 should correspond to summit surface also called for De Martonne, Superficie dos Campos e das Cristas Médias. These surfaces are deformed, according to the authors, by the tectonic effect and Cenozoic dissection.

The surface Pd2 would be processed from the Middle Tertiary, corresponding to surfaces interplateau with cycles of wet and dry phases. The age of this phase roughly corresponds to the cycle of Velhas de King. The opening of peripheral depressions that define depression corridors when crystalline contacts to sediments of Parana, Amazonas and Parnaíba basins, what Ab'Sáber called Neogenesis surface.

The surface Pd1 corresponds to areas in the process of sculpturing defined morphologically through alveolus inserted in Neogene South and Southeast surface, as well as the boards of Northeast coast which corresponds to Paraguaçu cycle by Lester King (1956).

Important contributions for understanding of the evolution of Brazilian relief were given by Ab'Sáber (1949-1960-1972) about the erosion surfaces. The identification by Ab'Sáber of regions in Brazil marks surround denudation Cenozoic was the first step to establish a sequence of levels or erosion surfaces, later (1960), which he called as "Posição das Superficies Aplainadas do Planalto Brasileiro". His proposal identifies four levels or flattening surfaces, so-called:

\section{$\checkmark$-Summit Surfaces, Interplateaus Surfaces,Fossils in Exhumation Surfaces and Eversion Surfaces.}

The Summit Surfaces include both surfaces: the so called Superficies de Campos, as the Superficies de Cristas Médias, previously identified by De Martonne. For Ab'Sáber, these surfaces match the former areas of erosion, now positioned at high levels (over 1000 meters) in the face to tectogenesis processes, warping due to epirogenesis post-Cretaceous. Interplateaus Surfaces correspond to Ab'Sáber, the large peripheral depressions surrounding sedimentary basins that would have been carved along the PliocenePleistocene. 
Fossils in Exhumation Surfaces correspond to the old flattening surfaces that were covered by sediments of large sedimentary basins which are nowadays in the process of exhumation. The Eversion Surfaces correspond to those areas that represent ancient exhumed surfaces. It Involves Cuiabana and Sertaneja depressions and the Amazonia- north and south that were covered by sediments from sedimentary basins that nowadays are exposed by erosive effect of newer phases.

Ab'Sáber (1972), in subsequent more systematized studies redefined flattening surfaces included in the subdivision of the Brazilian Plateaus, valuing the types of depressions in face to a genetic classification. The names of Depressions:

- Subsequentes; Monoclinais; Marginais com Eversão; Marginais com Eversão Formação de Bacias Detríticas.

The Periféricas Subsequentes Depressions, are represented by sculpted surfaces throughout the Neogene and Pleistocene, at the edges of sedimentary basins. These depressions are still characterized for being found inserted between the reverse side of a crystalline massifs by one side and relief of cuesta to another, which determined extensive depression corridors subsequently to the structure of sedimentary basins. This occurs, for example, with Depressão Periférica Paulista, Depressões Periféricas Sul Riograndense, or, as it is known: Depressão Central do Rio Grande do Sul.

The Monoclinais Depressions, as the name indicates, correspond to the depressions inserted edges of sedimentary basins. These depressions usually carved by hydrographic network which principal axis is anaclinal draining are individualized by Cuestas fronts. These depressions are found mainly in western and northwestern edge of Paraná Basin, pointing out Rio Taquari River (MS) and Rio Vermelho (region of Rondonopolis, Mato Grosso State). The Marginais com Eversão Depressions, were named for surrounding the edges of sedimentary basins, and being found carved in ancient rocks of crystalline massifs or older met sedimentary rocks. Eversion was named from the fact of these depressions present surfaces flattened by ancient erosion cycles (pre-Devonian) and having been buried by paleomesozóicos deposits of large sedimentary basins. And the Upper Cenozoic, after and during the epirogenesis events (Tertiary), have been partially exhumed by surround denudation erosion. In these genetic characteristics, set Cuiabana Depression (Mato Grosso State), Miranda Depression (Mato Grosso do Sul State), the Sertaneja Depression (Northeast), Tocantins Depression (Tocantins State) and the Northern and Southern Amazon. 
The Marginais com Eversão e Formação de Bacias Detríticas Depressions, correspond to those genesis similar to the previously described, adding to these the generation of detrital Cenozoic deposits. Among those presenting these deposits may be mentioned: the Alto do Paraguai Depression, with covering the Pantanal Formation (Pleistocene), and the Guaporé Depression, with coverage Guaporé Formation (Pleistocene), and Tectonic Depressions associated with rift valleys partially filled by sediments as the Plio-pleistocene Medio Vale do Paraiba in Sao Paulo, Rezende in Rio de Janeiro State, São Paulo Basin in high of Tiête river, the lower valley of Ribeira in Sao Paulo State, Curitiba in Parana State, among countless other less known.

Synthesizing a bit further, we can say that, in fact, the partitioning of relief in Brazilian territory becomes more comprehensible when using the concepts of Morphostructure and Morphosculpture by Gerasimov and Mescerjakov (1968).

Under the Morphostructure (landforms controlled by structure), there has been the major forms determined by old crystalline structures (cratons), orogenesis belts and sedimentary basins (paleomesozoic). On these great Morphostructure that exogenous processes (climate action) are acting and acted in the past, resulting in complex genesis of morphosculptures. However, besides the morphological complexity generated, by one hand for the climate past variations and on the other hand, by complexity litho structural, it means a large divisor in evolutionary history of Brazilian relief - the epirogenesis or generalized uplift, however uneven of South American terrace.

So if the occurrence of process of Meso-Cenozoic uplift is undoubted, but it is still difficult to affirm that it was a continuous or intermittent process. Thus, what there are in terms of relief subdivision in Brazil are, in fact, the influences of passive litho structure (morph structures), the influences of active tectonics (epeirogeny,-uplifts, faults, intrusions) and influences of active exogenous processes (climatic variations in time and space).

The old climatic influences (pre-Cenozoic), which resulted in extensive erosion and left indelible marks in the forms of relief particularly large, can still be observed by discontinuous residues of old flattening surfaces left in old morphostructures like cratonic or terraces areas and on topographic high levels of orogenic belts. Thus, the evidence of erosion surfaces or flattening ancient (pre-Cenozoic) appears at different levels of rectlinear surfaces: in the highest sectors of Cinturão do Atlantico (Serra do Espinhaço, Serra da Mantiqueira, reverse of Serra do Mar); in Cinturão de Brasília (Serra Dourada, Serra das Caldas Novas, Serra da 
Mesa, Chapada de Brasília, Chapada dos Veadeiros, in Goiás State); in Cinturão do ParaguaiAraguaia, in flat tops or rectlinears of Província Serrana (Serra Azul, Serra das Araras, Serra da Agua Limpa, Serra da Poção-Sabão, Serra da Bodoquema, in Mato Grosso State; Mato Grosso do Sul State) and Plataforma Amazônica and low destroyed areas of Cinturão Paraguai-Araguaia (Depressão Cuiabana and Miranda), Cinturão do Atlantico (Depressão Sertaneja), the latter corresponding to the Superfícies de Eversão defined by Ab'Sáber (1960, 1972).

The marks of Cenozoic erosional activities are observed by corridors of surrounding Depressions of sedimentary basins, whether they are peripheral, marginal or monoclinal. The Marginal Depressions, so named by Ab'Sáber (1972), were generated in the Neogene and Pleistocene, as the others, however, as being carved they exhumed ancient surfaces (pre-Devonian) that were buried by sediments of Phanerozoic big sedimentary basins.

Facts presented here, corroborate by formulating a new proposal for relief classification of Brazil, developed by Ross (1985/1990). This classification makes it quite clear large division of Brazilian relief under the influence of sculptural effects, by one hand, and structural by another. Under the concepts and Morphostructure, morphosculpture, that ultimately is the influence of W. Penck (endogenous and exogenous processes); Ross $(1985,1990)$ proposes dividing the relief of Brazil into Morphosculptures Units (incorporating morphostructural), defined as follows:

Units in Plateaus sculpted on morpho-structures of orogenesis belts, crystalline warping nucleus, sedimentary basins and Intrusions and residual coverings:

\begin{tabular}{|l|l|}
\hline \multirow{5}{*}{ On orogenesis belts } & $\begin{array}{l}\text { 1-Cinturão do Atlântico- Planaltos e Serras do Leste e Sudeste (serras do } \\
\text { Mar, Mantiqueira, Caparao, Orgãos, Espinhaço) }\end{array}$ \\
\cline { 2 - 2 } & $\begin{array}{l}\text { 2-Cinturão de Brasilia- Planaltos e Serras de Goias-Minas (Serras da } \\
\text { Canastra, Mesa, Dourada, Veadeiros, Brasilia) }\end{array}$ \\
\cline { 2 - 2 } & $\begin{array}{l}\text { 3-Cinturão Paraguai-Araguaia- Serras do Alto Paraguai (Bodoquena, } \\
\text { Província Serrana) }\end{array}$ \\
\hline \multirow{3}{*}{ On crystalline warping nucleus } & 1-Planalto da Borborema \\
\cline { 2 - 2 } On Sedimentary basins & 2-Planalto Uruguaio-sul riograndense \\
\hline \multirow{5}{*}{$\begin{array}{l}\text { Intrusions and residual } \\
\text { coverings of cratons: }\end{array}$} & 2-Bacia do Parnaiba- Planaltos e Chapadas da Bacia do Parnaiba \\
\cline { 2 - 2 } & 3-Bacia do Parecis- Planaltos e Chapadas da Bacia do Parecis \\
\cline { 2 - 2 } & 4-Bacia do Amazônas- Planalto da Bacia Amazônica Oriental \\
\cline { 2 - 2 } & 2-Planaltos Residuais Norte Amazônicos \\
\hline
\end{tabular}




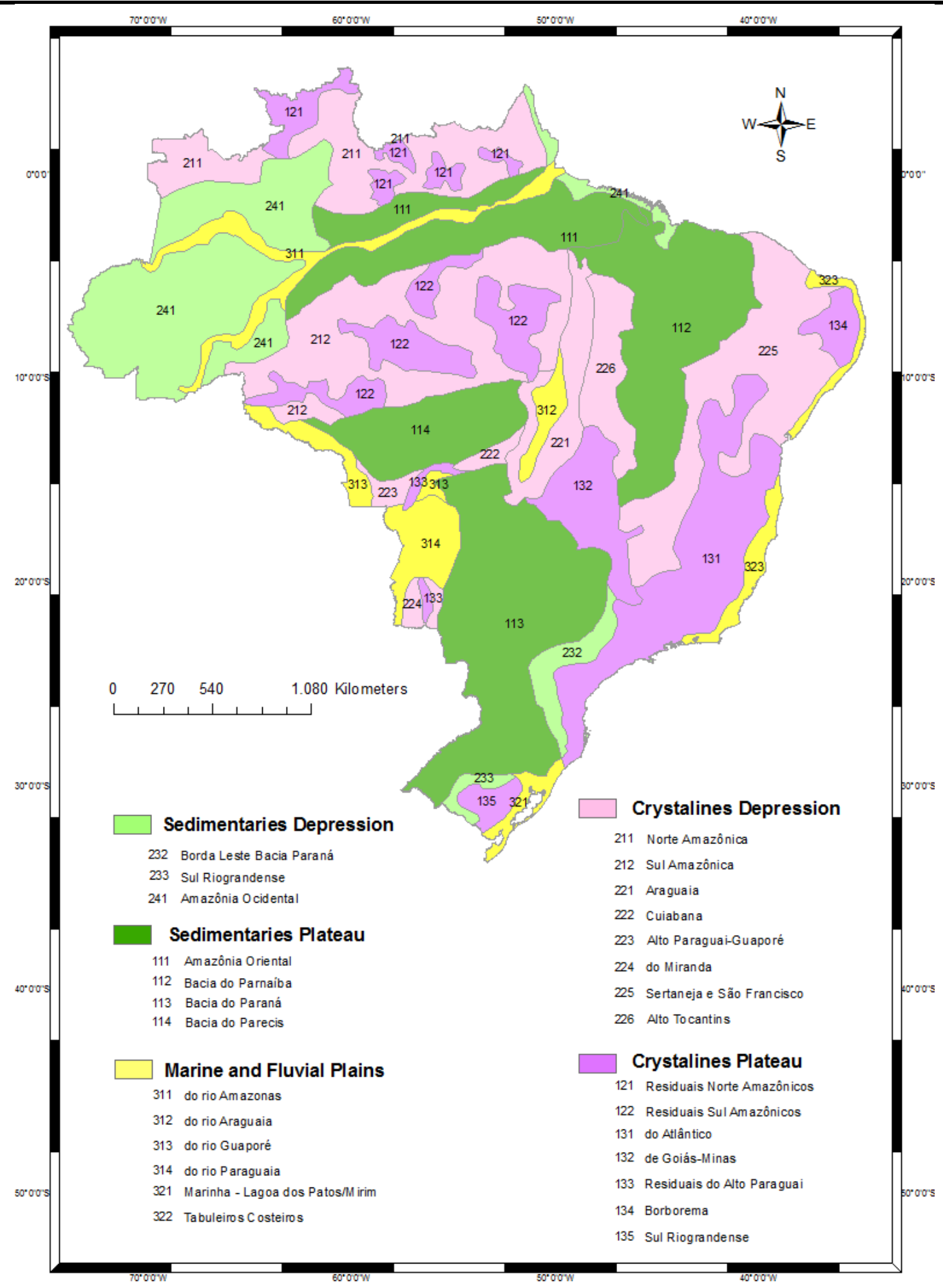

Figure 2: Great units of Brazilian relief (Ross, 2009 - Ecogeografia do Brasil).

The lowered surfaces flattened by erosion or deposition during the Cenozoic, located between the edges of sedimentary basins and ancient crystal structures, called in the literature as Interplateau Depressions of various types by Ab'Saber (1972), they are: 


\begin{tabular}{|l|l|}
\hline $\begin{array}{l}\text { Depressão da Amazonia Ocidental- na bacia do } \\
\text { Solimões }\end{array}$ & Depressão do Guaporé \\
\hline Depressão Marginal Norte Amazônica & Depressão do Miranda \\
\hline Depressão Marginal Sul Amazônica & Depressão Sertaneja e do São Francisco \\
\hline Depressão do Araguaia & Depressão do Tocantins \\
\hline Depressão Cuiabana & $\begin{array}{l}\text { Depressão Periférica da borda leste da Bacia do } \\
\text { Paraná }\end{array}$ \\
\hline Depressão do Alto Paraguai & $\begin{array}{l}\text { Depressão Periférica Sulriograndense ou Central } \\
\text { Gaucha }\end{array}$ \\
\hline
\end{tabular}

The flat surfaces, low and formed by sedimentary deposits of quaternary distinguish:

\begin{tabular}{|l|l|}
\hline Planícies do Rio Amazonas & Planícies da Lagoa dos Patos e Mirim \\
\hline Planícies do Rio Araguaia & Tabuleiros Costeiros \\
\hline Planícies e Pantanais do Rio Guaporé & $\begin{array}{l}\text { Pequenas Planícies Fluviais e Marinhas dispersas na } \\
\text { costa }\end{array}$ \\
\hline $\begin{array}{l}\text { Planícies e Pantanais do Rio Paraguai ou } \\
\text { Matogrossense }\end{array}$ & \\
\hline
\end{tabular}

This classification tries to value the genesis as a factor in setting the relief forms. Thus, geotectonic, great structures and sculptural processes are indispensable arguments for interpreting the great Brazilian forms of relief.

\section{Conclusion: Genetic Diversity of Morphological Levels}

In of view it had been exposed above, it is evident that we cannot establish a direct and absolute relation between the planning surfaces, the different morphological or topographical levels and the ages of the shapes. Although, some generalizations can be established regionally, assuming that the flattened levels or at least rectilinear of the tops of folding ranges (belts), are registers of ancient erosional phases (pre-Cenozoic) and that inter plateaus, as well depressions surfaces built on the edges of large sedimentary basins, are from a more recent age (Tertiary and Quaternary), because when the scale of analysis is increasing, it is necessary to evaluate what fits in the overall context and what is a particularity object of searching area.

The morphological or topographical levels, local or regional, may be associated with diverse backgrounds, and therefore their existences are associated to different genesis. Among genesis of morphological levels, one can point out the following:

$\checkmark$ Extensive flat levels or rectilinear and leveled tops straight flush, in a position to summit, testifying old of erosion surfaces, either Cretaceous or even the preCretaceous; 
$\checkmark$ Rectilinear tops positioned in two or more altimetry levels differentiated by tilted fault blocks by the effect of ancient tectonic reactivated in Meso-Cenozoic, generating horsts and grabens;

$\checkmark$ Tops leveled in different altimetric levels, carved from crystalline structures, by the effect of weathering and uneven geochemical lowering;

$\checkmark$ Levels in structural platform defining flat or flattened surfaces in sedimentary basins with alternation of tender and rigid lithologies, often on the edges of large sedimentary basins;

$\checkmark$ Levels in structural staggered heights setting flat or low-slope ramps, conditioned by lodging plans for different phases of volcanic lava flows acidic and basic common in the Paraná basin;

$\checkmark$ Ancient flattened Surfaces, buried by sedimentary deposits and later exhumed, located at the edges of sedimentary basins called Eversion Surfaces or Marginal Depression;

$\checkmark \quad$ Lowered and flattened Surfaces by erosion generalized, located between the edges of sedimentary basins and old massifs, called peripheral depressions;

$\checkmark$ Surfaces flat tops positioned in reverse escarpment edges of sedimentary basins, named Highlands and Tablelands(Plateaus);

$\checkmark$ Levels of different tops occurring local or regional bodies associated with intrusive or volcanic / granites, syenites, or rhyolites, andesites;

$\checkmark$ Levels associated with different stages of deposition / erosion Cenozoic, tectonic depressions housed in closed or semi-open;

$\checkmark$ Small levels associated with different stages of Quaternary deposition and/ erosion of fluvial, ,lake or sea..

We avoided in this work is to discuss the controversial issues about the climate effects and paleoclimate in the context of sculptural processes. We are purposely treating these processes generically as erosive of different phases, in face to the obvious difficulties of the proofs, by a lack of correlative deposits that are configured reliable proof. Much of the known deposits correlative phases of erosive pediplanation taken in the literature, as evidence of arid or semi-arid, consist of fragmentary materials quartz morphologies and angular dimensions heterométric. These materials often come from quartz veins of quartz contained in meta morphic rocks like schists, phyllites, migmatites among others. As the 
pebbles shaped fragments of quartz (silica), are poorly soluble, ultimately remain accumulated in the form of discontinuous layers (Stone lines) in the mantle of change of these rocks and dominantly accumulate residually between the $\mathrm{C}$ horizon of the parent rock and $\mathrm{B}$ horizon represented by the pedological covering, almost always following the morph logy of the strands. They also occur in valley bottoms and plans mainly terraced, when mingle and blend with pebbles of fluvial deposits of the same composition.

Vitte (1998) to study the morphogenetic processes of Ribeira basin in the range of Atlantic Belt, is in line with what Ross $(1987,1991,1998)$ concludes by analyzing the evolution of relief in orogenesis belts. It can be noticed that the altimetry variations and configurations are associated with morphological complexity of processes involving tectonic Precambrian, reactivation of meso-Cenozoic tectonics, litho-structural arrangements of banding, old erosion levels dismantled by tectonic old erosion surfaces exhumed by Cenozoic erosion and mainly by morphological unequal downgrades activities arising from geochemical waters.

Even so, the evidence in this direction by Ross and Moroz (1997) and Ross (1998) that different levels of morphological and topographical found in the plateaus of São Paulo State eastern, in the Atlantic Belt, are related to a complexity of morphogenetic processes which occur in space and time and involve tectonic activities of different ages and genesis, such as folds, metamorphism, magmatism, old faults, reactivation of faults in the Cenozoic, together with evidence of ancient erosion surfaces.

In this region, Ross (cited above) call attention for different morphological and topographical levels, that are observed among the structures represented by the masses of rock like granite of the ridges: Itapeti, Cantareira, Itaqui, San Francisco, San Roque, Paranapiacaba, Caparao, Bocaina, Organs, among many others, that are on altimetry levels among 850, 900 to 1000,1400 meters. They are beside the reliefs carved in quartzite rock masses, as Jaragua Peak, Serra do Japi, Serra de Voturuna, Canastra and Espinhaço, which tops are between 1100 and 1200 meters.

Around these prominent reliefs, lies a vast area which tops are flush around 800 meters of altitude that are predominantly sculpted in metamorphic gneisses and migmatites especially interspersed with extensive schists and phyllites tracks that are often in lowered topographically positions.

These facts led Ross (1998) to consider for the plateaus of Band Belt Atlantic of São Paulo State that: 
$\checkmark$ "The evolution of the topography of the region, has in tectonic Meso-Cenozoic processes, important as a trigger for vigorous sculptural processes, both on the slopes of the Serra do Mar and Mantiqueira, as the tops of plateaus surfaces, ....".

$\checkmark$ "Sculptural processes such as were present in the pre-Cenozoic and created significant differences in altimetry, according to variations depending on lithological and structural arrangements of these, not being necessarily distinct erosion surfaces, but downgrades uneven surface relief by geochemical processes resulting from humidity and temperature and river mechanics. "

$\checkmark$ "Deposits in Cenozoic sedimentary basins of fines (clay) being relatively inexpressive in extent and volume in front of extensively of strongly dissected relief areas; it suggests predominance of wearing processes (erosion and transport) for chemical dissolution of primary minerals, remaining in situ only the "residual" of geochemical processes."

$\checkmark \quad$ "The presence of higher reliefs maintained by massive igneous rocks (granites) and metamorphic rocks (quartzite) surrounded by lower reliefs sculpted in metamorphic rocks that have a higher density of lines of weakness, also suggest to the prevalence of erosive wearing from geochemical processes, therefore lowering geochemist. It is considered that the weathering process of rocks consisting of mineral primary and secondary minerals in the transformations that comprise the pedological cover and deposits Cenozoic is a significant sculptural process where dissolved minerals are transported into the ocean water, remaining on continents quartz sand residues and the still more stringent fine materials (clay). "

Thus, even if we have scant evidence past that in times there were drier climates that contributed to sculptural processes of regional relief, the geochemical activities of humid and preferably hot environments, that by one hand set a definite mark in the processes morpho sculptural of relief forms on ridges, hills and mountains, and on the other hand, the processes and arrangements morphotectonic and morphostructural along with the differences in wearing resistance of different families of rocks, those set the parameters for understanding the tropical morph genesis. 
BIBLIOGRAPHY

AB'SABER, A.N. (1949) Regiões de Circundenudação Pós-Cretáceos no Planalto Brasileiro. Boletim Paulista de Geografia 1. São Paulo, 1-21.

AB'SABER, A.N. (1960) Posição das Superfícies Aplainadas no Planalto Brasileiro. Geomorfologia 20. Campinas, 10-22.

AB'SABER, A.N. (1969) Um conceito de Geomorfologia a Serviço das Pesquisas sobre o Quaternário. Geomorfologia 18. IGEOG - USP. São Paulo. 15p.

AB'SABER, A.N. (1972) Participação das Depressão e Superfícies Aplainadas na Compartimentação do Planalto Brasileiro. Geomorfologia 28. IGEOG - USP. São Paulo. 20p.

ALMEIDA, F.F.M. de (1964) Os Fundamentos Geológicos do Relevo Paulista. DNPM/DGM, Boletim 41. Rio de Janeiro, 1-60.

ALMEIDA, F.F.M. de (1967) Origem e evolução da Plataforma Brasileira. DNPM/DGM. Boletim. Rio de Janeiro, 22-45.

BIGARELLA, J.J. e MOUSINHO, M.R. e SILVA, J.X. (1965) Contribuição ao estudo da Formação Pariquera-Açu. Boletim Paranaense de Geografia. Curitiba, (16/17): 17-41.

DE MARTONNE, E. (1943) Problemas Morfológicos do Brasil Tropical Atlântico. Revista Brasileira de Geografia 4, ano V, IBGE. Rio de Janeiro, 4-25.

KING, L.C. (1956) A Geomorfologia do Brasil Oriental. Revista Brasileira de Geografia 18. Rio de Janeiro, 1-120.

MESCERJAKOV, J.P. (1968) Les Concepts de Morphostruture et de Morphosculture: un nouvel instrument de l'analyse géomorphologique. Annales de Geographie 423. 539-552.

ROSS, J.L.S. (1987) Estudo e cartografia geomorfológica da Província Serrana. MT, Tese de Doutorado apresentada à FFLCH/USP. São Paulo.

ROSS, J.L.S. (1990) Relevo Brasileiro: Uma nova proposta de classificação. Revista do Departamento de Geografia , 4. FFLCH/USP. 25-39. 
ROSS, J.L.S. (1991) O Relevo Brasileiro, as Superfícies de aplainamento e os Níveis Morfológicos in Revista do Departamento de Geografia, 5. FFLCH/USP. São Paulo. 7-24.

ROSS, J.L.S. (1991) O Contexto Geotectônico e a Morfogênese da Província Serrana de Mato Grosso. Revista I.G. São Paulo, 12(1/2):21-37.

ROSS, J.L.S. e MOROZ, I.C. (1997) Mapa Geomorfológico do Estado de São Paulo - escala 1:500.000. FFLCH-USP-IPT-FAPESP. São Paulo. 64p.

ROSS, J.L.S. (2001) Geomorfologia e Geografia Aplicadas à Gestão Territorial: Teoria e Metodologia para o Planejamento Ambiental. Tese de Livre Docência apresentada à FFLCH/USP. São Paulo. 322p.

ROSS, J.L.S. (2002) A Morfogênese da Bacia do Ribeira do Iguape e os sistemas ambientais. Revista GEOUSP, 12. São Paulo, 21-46.

VITTE, A.C. (1998) Etchplanação em Juquiá (SP) - Relações entre o Intemperismo químico e as mudanças climáticas no desenvolvimento das formas de relevo em margem cratônica passiva. Tese de Doutorado apresentada à FFLCH/USP. São Paulo. 276p.

\section{Artigo recebido em 30/05/2013}

Artigo aceito em 03/07/2013. 